\title{
AN EFFECTIVE SOLUTION OF SEWAGE TREATMENT
}

\author{
AND DISPOSAL BY CHEMICAL TANK AND BACTERIAL FILTER.
}

\author{
By DOUGLAS ARCHIBAT, D.
}

$\mathrm{T}^{\mathrm{T}}$

THE side of human progress is for ever on the ebl and flow. To-day we are carried on the flood towards what promises to be the long sought for complete solution of our problem. To-morrow we drift back with the ebb towards its exact anti-type.

Meanwhile, in our rush from the one extreme to the rither, we too often neglect the intermediate zone, the vin media, which by welding together the adrantages, and discarding the disadvantages, gives us a composite solution rastly superior to that effected by either component acting alone.

The importance of such a mental attitude is especially great just now, when a ware of sentiment is passing over the world in favour of biological purification of sewage, and all chemical or so-called artificial methorls, are regarded as objectionable and obsolete.

As too often happens in such cases, a blind rush has been made towards this latest El Dorado, similar to that which some years back took place when chemical treatment in tanks burst upon the world as the long looked for alchemist's dream, by which sewage could not only be purified but converted into a manure which would realise such a price as to cover the entire cost of treatment from start to finish.

And here it may be pointed out that just as this error arose in the purely chemical treatment, from a neglect of the various items of cost, so the apostles of purely biological treatment appear to be rushing into a similar error in regarl to its assumed economy by their neglect of the various items connected with the disposal of the suspended solids through tanks and filters, the capacity of both required to effect the requisite purification, and the cost of periodical renewal of filter material when the latter become choked with the solids which in a properly conducted 
chemical scheme would be all deposited at the base of the preliminary tanks.

Some three or four years back, when the so-called Sutton double contact, without tanks, and the Exeter septic tank and single or double contact systems were started, we were all led to believe:

(1) That practically speaking there would be no sludge deposited in the tanks.

(2) That one or two contacts would effect the highest purification.

(3) That there would be no difficulties in connection with filter renewal.

(4) That the disuse of chemicals would involve a great saving not only in material but also in labour.

Now, in the light of the practical results of experiments, what do we find?

(1) It is admitted by Dr. Kenwood and Dr. Butler as a result of their experiments that only from 30 to 40 per cent. of the solids are digested in the tanks.

A review of all the recent septic tank experiments at Leeds and Leicester gives as a joint average similar results. Thus, from sewage containing in each case 44 grains of suspended solicls, we find dissolved in the tanks 17 grains, = $3 \$ \frac{1}{2}$ per cent.; deposited in the tanks $15 \frac{1}{2}$ grains, $=35$ per cent. ; left in the tank effluent $11 \frac{1}{2}$ grains, $=26 \frac{1}{2}$ per cent.

Here, then, not only do we find that the amount dissolved is less than 40 per cent., but that the remaining 60 per cent. is not deposited at one point as it would be in the case of a thorough chemical precipitation, but is divided between the tank and the tank effluent, and hence causes that sludging up of subsequent filters which is creating such dismay among the upholders of bacterial tank treatment. At Exeter I find the proportions are similar, viz., 41 per cent. only, dissolved, and 59 per cent. distributed between the tank and filter.

The question at once arises: Is it worth while, for the sake of saving 40 per cent. only of solids, to at once discard all chemicals, and possibly incur counterbalancing expense in attendant drawbacks?

I hope to be able to show that it is not so, but that a juclicious blencling of chemical tank treatment and bacterial contact will constitute a "modus vivendi" between the opposing camps, besides effecting the maximum economy.

(2) Notwithstanding a general impression to the effect that the puritication produced by the purely bacterial process is high, I find upon an 
examination of the large amount of clata that are now available, that in most cases eren after several contacts, or after one or two contacts after septic tanks, the purification in no case exceeds what can be accomplished with a tank and single contact filter when adequate chemicals are employed in the former.

Thus, in the Leeds experiments, the highest purification, as measured by the albuminoid, was effected between Oct. 27th, 1898, and Oct. 9th, 1899 , and may be seen below.

Albuminoid ammonia in grains per gallon. Purification per cent.

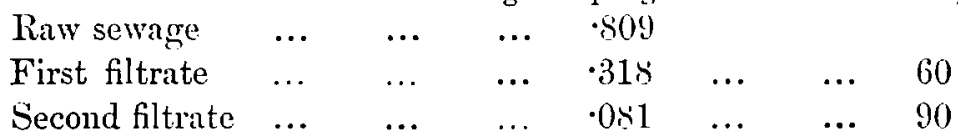

but this was not afterwards sustained, and I have found no others, even where continuous filters have been employed after septic tank, to equal this.

Moreover, on examining the rate at which the filters at Leeds were sludging up, which will be referred to later, such purification was evidently being accomplished under circumstances which may be described as involving a rapid waste of the filter potential or capacity.

The average of the general results at Manchester, Leeds, Leicester and Knowle gives a final puxification of barely 80 per cent. upon the raw sewage, as measured by the albuminoid ammonia. The results of the purification as measured by the oxygen absorbed for the same group with London substituted for Knowle, gives an arerage of 83 per cent. Now these are not remarkably high figures, even were they attended by no filter losses. 80 per cent. purification is frequently obtained by a good chemical tank eftuent, and if 70 per cent. upon this is attained after a single filtration, we have at once a final purification of 94 per cent. upon the crude sewage.*

The final filtrates from raw or non-chemically treated sewage are thus no purer as a rule than the direct effluents from chemical tanks, and except in cases where the original sewage is weak, would ordinarily violate the present river standards.

The reason for this low degree of purification attained after septic tank and contact filtration, is readily seen when it is remembered that the very plan by which the 40 per cent. of solids in the bacterial tank are sought to be eliminated by digestion, throws exactly so much extra work upon the

* Ey the simple formula $r=p+q-p q$, where $p$ and $q$ are the crude to tank, and tank to filter, percentages, and $r$ is the total percentage from crude to filter. 
agents, which tend to effect a simultaneous reduction in the dissolved impurities in the menstruum. Hence the purification effected upon the crude sewage by a septic tank is at most but 60 per cent. and since the avcrage purification claimed for one contact filtration of a bacterial effluent is about fifty per cent., the two together would exactly produce a final purification of only 80 per cent. upon the crude sewage.

(3) The question of filter sludging and renewal of material is one which is rapidly assuming great importance. In fact, the rapidity with which the contact filters at Leeds have been found to sludge up when dealing with crude sewage, delivered on to them without previous tank sedimentation, or septic tank treatment, has dealt a death-blow to the general acceptation of the "Sutton" system, inaugurated by Mr. Dibdin, which was started with so much confidence and was at one time considered to be about to render not merely previous chemical tank treatment unnecessiry, but the use of tanks altogether. To realise how enormous this sludging is and what an effective bar it constitutes to the practical carrying out of the tankless double contact system at Leeds, I need only quote the following from Mr. Harding's report :

"Only by working them (the beds) at the rate of one filling of 25,000 gallons per 24 hours, could the continued life of the rough bed be secured, and even then the ultimate choking seems inevitable owing to the retention in the beds of matters which have reached an irreducible condition, and which could not be consumed by resting the beds."

Since the rough and fine beds at Leeds are together equal to an area of half an acre, one yard deep; this means that to secure even a temporary respite from ultimate destruction it is only possible to filter one million yallons per day over an area of twenty acres of filter one yard deep!

Such an area of filter would evidently be impracticable from the point of view of expense alone, not to mention that of area.

When smaller areas of contact bed are used, the rate of sludging up on the other hand becomes equally prohibitive.

Thus the rates of sludging up of the primary contact beds at the following places, are as below:-

\begin{tabular}{|c|c|c|c|c|c|c|c|c|}
\hline \multirow{3}{*}{$\begin{array}{lr}\text { Leeds } & . . \\
\text { Manchester.. }\end{array}$} & \multicolumn{3}{|c|}{$\begin{array}{l}\text { Total days of worling } \\
\text { various } \theta \text { periments. }\end{array}$} & \multicolumn{3}{|c|}{ 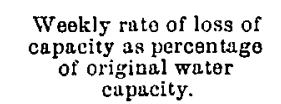 } & \multicolumn{2}{|c|}{$\begin{array}{l}\text { Time in months } \\
\text { when the ditter } \\
\text { is choked. }\end{array}$} \\
\hline & $\ldots$ & 487 & $\ldots$ & $\ldots$ & $2 \cdot 1$ & $\ldots$ & $\ldots$ & 13 \\
\hline & $\ldots$ & 220 & $\ldots$ & $\ldots$ & $1 \cdot 0$ & $\ldots$ & $\ldots$ & 22 \\
\hline London $\quad .$. & $\ldots$ & 525 & $\ldots$ & $\ldots$ & $1 \cdot 3$ & $\ldots$ & $\ldots$ & 19 \\
\hline & \multicolumn{2}{|c|}{ Averages } & $\ldots$ & $\ldots$ & $1 \cdot 4$ & & & 18 \\
\hline
\end{tabular}


After septic tank treatment the sludging is not so rapid, but it amounts at-

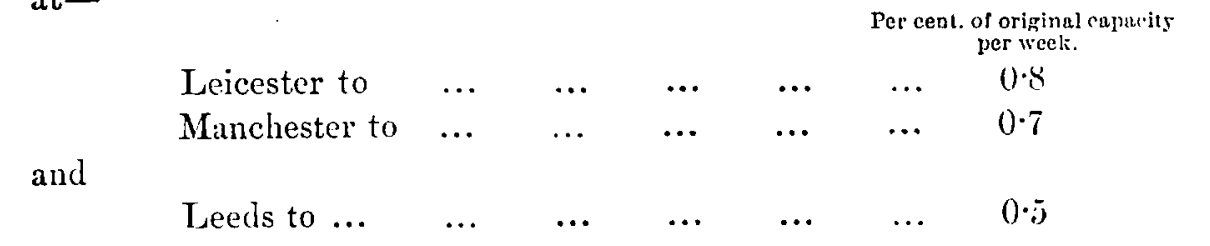

The arerage of these grives $0 \cdot 6$ per week, and the total duration of a little over three years for the filter to hold anything at all. Long before this limit is reached the filter material would have to be renewed.

(4) The amount of saving which was supposed to be effected by the disuse of chemicals in the tank has always been a powerful vis a tergo in helping to favour a purely biological system of treatment even in the tanks. This saving was made to embrace not merely the item of chemicals used, but also all the expenses of pumping, pressing, and removing the tank sludge.

That these latter expenses are in practice by no means sared, is obvious when it is considered that from the Leeds and Leicester results only $38 \frac{1}{2}$ per cent. of the total suspended matter, and therefore about the same proportion ( $\frac{2}{5}$ ths) of the total sludge in an ordinary chemical system, is dissolved in a septic tank, while about the same proportion is still deposited as septic sludge.*

In most cases where chemicals are used sparingly, say not more than 10 grains per gallon, the proportion deposited in the septic tank would vary from about one-third to one-half of the sludge deposited in a chemical tank.

This sludge las to be remored, and though on small experimental

* The amount of wet sludge deposited by chemical precipitation appears to be no more, and very often less, than what is represented by the total suspended solids in the sewage, quite apart from the weight of chemicals added.

This is probably due to three separate ciluses. (1) Where the precipitant is fairly soluble it of course adds little to the sludge. (2) A certain amount of suspended matter is usually found in an orlinary chemical tank effuent, and this would tead to counterbalance what was added by the chemicals. The third cause is one which I have nowhere seen discussed, and that is the probability that septic solution takes place almost as readily in a tank where moderate doses of chemicals are added as when they are absent.

If septic solution occurs in Manchester sewage, $\frac{1}{2} y_{3}$ ths of which is trade refuse aud chemicals, the same solution nust be admitted to occur where 10 grains of chemicals are added to a sewage containing 30 grains of suspended matter, aud an equal or greater amount of dissolved matter.

Admitting the premiss, it is plain that the sludge in a tauk where precipitating 
scales, such as have been in vogue, its removal is said not to have involved serious expense, it has admittedly entailed great nuisance at Leicester* and Leeds, and on a large scale would involve at least half the labour and expense of chemical sludge.

Moreover, septic sludge is in a most unfit physical condition to be dealt with readily in the presses, and further, being derived by simple deposition of the heavier and less reducible suspended matter, and containing theoretically none of the more valuable dissolved matter, it is of no manurial value and therefore useless lumber.

The amount deposited in the Leeds and Leicester experimental tanks gives 3,596 tons of 90 per cent. wet sludge, per annum, for a daily flow of one million gallons.

For a town of 50,000 inhabitants therefore, with an average daily flow of 40 gallons per head, or $2,000,000$ gallons, the total annual quantity of septic sludge would amount to no less than 7,192 tons. Such a quantity, unless pressed and removed, would constitute a grave nuisance and danger to the neighbourhood.

(4) The actual saving in chemicals moreover is more imaginary than real. In their endeavours to effect economy in chemicals many authorities have so attenuated the doses applied that they have not only damaged the credit of chemical treatment, but have hardly left anything to be saved.

In the case of Manchester, with a population of 520,000 , much was made of the great saving that would accrue by the abandonment of chemicals, but when the actual expenses are gone into, the saving is seen to be not more than $£ 5,000$ per annum, and this appears quite insignificant for such a population.

That the amount in this case must be small is plain when it is understood that only six and a quarter grains of lime, and six grains of sulphate of iron per gallon have been used. At London, where the dose had only

chemicals are added, would in general tend to be considerably less than that represented by the equivalent of the suspended matter in the sewage, plus the added chemicals. I am omitting the consideration of any material portion of the bulk of the chemical sludge being due to a precipitation of any large portion of the dissolved matters in the sewage, eince this has always been streunously denied by the anti-chemical section, and its aduission by them in this case would land them in the dilemma that the more organic material is remover from solution as sludge, the less is left in the eflluent.

* At Leicester Mr. Miwwey, in his Report, sily :-_"The sludge discharged from these tanks was so extremely offensire that the smell could not be escaped on any side, although there was a fair wind blowing at the time." This is certainly contrary to wluat Doctors Kenwood aud Butler allegre on pp. 105-(i.

rol. xxil. PART II. 
heen 3.8 grains per gallon, the cost and imaginary saving would be still less.

The supposed saving at Manchester when the double contact method was originally proposed, was assumed to be much larger, approximating to the 115,000 a year which included the labour and expenses of removing sludge from the tanks, but as time has progressed and the experts have gained experience, not merely has the idea of placing raw sewagre on the filter beds been absolutely discarded, but amongst the "later improvements" sugrested in their report, they recommend the use of the existing touks by which "the contact beds could be protected from receiving not. only the mineral detritus of the crude sewage, but also as much as possible. of the suspended organic matters contained in the latter." They even went so far as to say that it would be desirable "that the sewage passing on to the bacterial beds should by means of these tanks be "free from suspended matter."

Surely this is a veritable louleversement of the hypothesis with which they started, and an admission of the necessity for previous chemical tank treatment, for by no other means can the sewage be rendered free from suspended matter, since it is universally recognised that a septic tank effluent contains at least 10 grains per gallon, and sometimes, as Dr. Kenwood and Dr. Butler have recently shown, as much as 21 grains.

In any case a considerable portion of the remainder of the $\$ 15,000$ at Manchester, represented by labour and sludge removal, would still have to be met even if the chemicals were disused, and if we admit, a possible saving of $\mathfrak{f} 7,000$, or threepence per head per annum, it hardly seems to justify the inauguration of a scheme which starts off with a capital expenditure of $£ 487,000$ and endless charges for the renewal of 92 arres of filters.

Without going further into the question of the disabilities of total bacterial treatment, I now wish to point out that while the theory and practice of filtration of a tank effluent has undoubtedly been much improved by the various experiments, which have been made in contact anl continuous filtration, the practical difficulties of dealing with the suspended solids, and the resulting sludge have not been solved by the bacterial hypothesis, and we are virtually brought back to preliminary tank treatment and to adequate chemical tank treatment as the only wiy by which the subsequent filtration can be effected without detriment to the filter, and on an area which would be practicable within urban precincts.

And here we are met with the plain question: Has the chemical tank precipitation been fairly tried, and in what respect has it been found 
wanting? The real answer to this question must be sought for in the accepted fact that chemical tank sludge, even when pressed, has not been generally salcable at any price, and in the prevalent notion that it is incapable of being made to contain enough of the manurially valuable constituents of sewage to realise a grood sale price. In most cases also it has never been prepared beyond the stage of mere pressed cake, so as to be practically serviceable to the agriculturist.

Two questions are here involved: first, that the use of adequate and proper chemicals not merely may effect a proportionate purification of the tank effluent, but also a simultaneous enrichment of the resulting sludge; secondly, that the final drying of the pressed cake into a poudrette may render it easily adaptible to the land, a point which has been overlooked by those who have considered that the business ended with pressed cake and delivery to the farmer.

Though some persons are still sceptical in regard to the substantial purification effected by chemicals, it is generally admitted that the degree of purification ceteris paribus increases up to certain limits with the quintity employed.

Dr. J. Carter Bell's classical experiments at Salford prove this fact conclusively. Thus, in his paper, "On the Comparative effect of Lime and other chemicals on Sewage," he says: "With 10 cwt. of lime very little purification took place, and even 15 cwt. did not give a brilliant effluent. It was not until $20 \mathrm{cwt}$. (15.68 grains per gallon) was reached that any satisfactory purification took place." . . . .

In the case of Sulphate of Alumina the same per saltum increase appears. at a rather higher point, and the general evidence of the high purification thus secured is so strong that I quote the table here.

\begin{tabular}{|c|c|c|c|c|c|c|c|c|c|}
\hline $\begin{array}{l}\text { Sulph } \\
\text { Alum } \\
\text { million }\end{array}$ & $\begin{array}{l}\text { te of } \\
\text { a to to } \\
\text { allons. }\end{array}$ & & $\begin{array}{l}\text { Albuminoid } \\
\text { Aumonia. } \\
\text { (irs. per gall. }\end{array}$ & & $\begin{array}{l}\text { Percentage } \\
\text { Purification. }\end{array}$ & & $\begin{array}{l}\text { Oxygen for } \\
\text { fuir hours. }\end{array}$ & & $\begin{array}{l}\text { Percentage } \\
\text { l'urification. }\end{array}$ \\
\hline & $w+$. & $\ldots$ & $0 \cdot 349$ & & $10 \cdot 3$ & $\cdots$ & $\pm \cdot()$ & $\cdots$ & $2 \cdot 4$ \\
\hline 10) & " & $\ldots$ & $0 \cdot 266$ & $\cdots$ & $40 \cdot 2$ & $\ldots$ & $3 \cdot 8$ & $\ldots$ & $7 \cdot 3$ \\
\hline 15 & ,. & $\ldots$ & $0 \cdot 250$ & $\cdots$ & $43 \cdot 8$ & $\cdots$ & $3 \cdot 6$ & $\ldots$ & $12 \cdot 1$ \\
\hline 20 & , & $\ldots$ & $0 \cdot 238$ & $\ldots$ & $46 \cdot \overline{3}$ & $\ldots$ & $2 \cdot 8$ & $\ldots$ & $31 \cdot 7$ \\
\hline 30 & , & $\ldots$ & $0 \cdot 105$ & $\ldots$ & $76 \cdot 4$ & $\ldots$ & $1 \cdot()$ & $\ldots$ & $75 \cdot 6$ \\
\hline 40 & , & $\ldots$ & $0 \cdot 100$ & $\ldots$ & $77 \cdot 5$ & $\ldots$ & $0 \cdot 94$ & $\ldots$ & $77 \cdot 0$ \\
\hline
\end{tabular}

Now if such a high purification as $71 i$ per cent. can be obtained on the settled sewage* by the use of sufficient sulphate of alumina, KTA, it is

* Dr. Bell made all his purification numbers from settled sewage. 
evidently not because chemical treatment is incapable of effecting a very large purification that it has been labelled ineffective and obsolete, but owing to the assumed concomitant and unbalanced expense of chemicals.

With their eyes set upon economy, laving only one object, viz., to give the minimum dose that could leave the maximum permissible impurity in the effluent, and not caring to trouble themselves to realise the full value of the sludge; the local bodies in charge of sewage works have in general never tried a real chemical tank process on the above scale. They hare thus, by a false economy in materials, not mercly missed the benefits of a real chemical treatment, chosen so as to simultaneously produce a high purification and a valuable sludge, but have unfortunately given chenical treatment a bad name.

When a treatment dwindles down to a dose of three grains per grallon, as at Crossness, and is still labelled chemical treatment, and referred to by Dr. Clowes in his reports on Bacterial Treatment of London Sewage, as though its shortcomings were typical of chemical treatment grenerally; it is high time to define limits and say what is, and what is not clemical treatment.

Obviously 5 cwt. per million gallons of sulphate of alumina, producing only 10 per cent. purification, is not worthy of the name, and yet such a treatment is gravely put forward by Dr. Clowes, with its 16 per cent. purification in comparison with an effluent from double bacterial filtration which, it may be noted, gives a purification below some in Dr. Bell's table of chemical tank effluents above.

Surely it is better for the final economy by the sale of what may be termed residual products, to apply a generous dose in the tanks, precipitate all the solids within the tanks, sccure a tank effluent with a purification of from 70 to 80 per cent., and filter once if necessary on a small area, than to use the same or a larger area of tanks without chemicals, and supplement it by two sets of filters of much larger area (four and a half times that in the former case), witl all the sludge difficulties which have been already mentioned, and with doubtful results as to final purification.

The problem has certainly been solved in one case, and before communities plungre recklessly into the extensive tank and filters required for entire bacterial treatment, it would be well for them to examine the solution which has been practically worked out for a population of orer 50,000 , on a site surrounded by buildings, and bordering on a river promenade. I allude to the system in vogue at Kingston-on-Thames, with a population of 50,000 . Here, if anywhere, chemical precipitation may be seen in its ideal form, i.e., where the solid products are absolutely 
disposed of by sale. Hampered by no council demanding false economy, encouraged by the unceasing demand for the guano, the company which works this system puts in their special chemicals, including a large amount of precipitating salts of alumina with a prodigality which is fully endorsed by the results. 50 grains per gallon is a large quantity, but the results prove its wisdom.

The materials, a modification of the original A B C mixture, have this unique property that they produce a purification amounting to orer 80 per cent. in the albuminoirl ammonia and the dissolved organic matter, a complete precipitation of all suspended matter, ${ }^{*}$ and a sludge which when pressed and dried, commands a free sale at $\mathscr{E} 310$ s. per ton.

The precipitation is very expeditious, being conducted by a continuous flow through tanks which only hold about three-fifths of an average day's flow, and the operations are conducted on an area of only two and a half acres, virtually in the centre of a town and within a few feet of a public promenade and a bandstand.

The tank effluent has hitherto flowed direct into the river, but to meet the recently increased stringency of the Thames Conservancy requirements, it is proposed to erect one and a quarter acres of contact bed, three feet deep, of a type similar to that which has been experimented with for the last three years by the company.

The actual purification effected in the tanks alone and with the additional filter may be judged of by the following figures for the albuminoid ammonia in the various effluents.

Kingston-

\begin{tabular}{llllrllll} 
& & \multicolumn{4}{c}{ parts per million. } & \multicolumn{3}{c}{ per cent. } \\
Raw sewage & $\ldots$ & $\ldots$ & $\ldots$ & $12 \cdot 46(a)$ & $\ldots$ & $\ldots$ & \\
Tank effluent &.. & $\ldots$ & $\ldots$ & $2 \cdot(17$ & $(b)$ & $\ldots$ & $\ldots$ & 83 \\
Filtrate & $\ldots$ & $\ldots$ & $\ldots$ & $0 \cdot 74$ & $(c)$ & $\ldots$ & $\ldots$ & 94
\end{tabular}

(a) A mean of hourly samples for a whole week.

(b) A mean of two years' frequent analyses (192) by the medical officer of health at Kingston, and the Company's chemist during 1898 \& 1899.

(c) A mean of three year's' analyses by the latter.

* Fifty samples of the tank efluent yielded an average of 0.09 grains jer gallon, which is practically nothing. 
The experimental filter, with which the final results have been obtained, is filled with coke-breeze of medium coarseness, and is about $2 \frac{1}{00}$ th of an acre in area, and 3 feet in depth.

Its capacity has not sensibly altered during the whole period. Measured to hold 1,400 gallons after the first filling, it had only diminished to 1,265 gallons, after two ycars and nine months.

Taking the true mean capacity from four measurements, as 1,275 gallons, it has, with six fillings per twenty-four hours, accommodated $1,530,000$ gallons per acre. But this measure is probably an underestimate, and if we take the ordinary rule that initially the capacity of the filter was 4.9 per cent. of its empty capacity, ${ }^{*}$ and allow for the slight reduction during the period, the mean capacity comes out about 1,800$)$ gallons for $\sum^{1} 0^{-t h}$ acre, and thus at six fillings per day about $2,160,000$ gallons can be passed over an acre.

The purification effected on the tank effluent at three, four, and six fillings per 24 hours, has varied from 66 to 70 per cent., and when the absence of sludging, due no doulbt to the entire alsence of suspended matter, is taken into consideration, I think the results are unequalled for economy of area, material, and purification.

Turning to the sludge, we find that what is usually the drawback to all precipitation schemes is converted into an innocuous material, which is sold as fast as it is produced; and there is every cvidence to show that the sale has been effected chiefly to old customers and with little advertisement.

That there is no nuisance attendant upon the normal working of the process may be gathered from the recent report made by Prof. Wanklyn, after a detailed examination of the works at Kingston, in which, while referring to certain surrounding causes of nuisance, he entirely exempts the sewage works.

When the question of price is considered, I think this particular system of precipitation and filtration will be found to compare very favourably not merely with existing precipitation schemes, where the chemicals are ordinarily attenuated because there is no chance of partly repaying their cost by the sale of the sludge, but also with what will be the probable cost of purely bacterial schemes when the capital cost of works, filters, and land, and the renewal of filters and removal of septic sludge are properly allowed for. For example, to take the annual cost of

* This is a rule which follows from all the recent leading filter measurements at Leeds, Leicester, Manchester, and London. 
the treatment alone, I fincl upon examination that while the averige annual expenses of treatment and disposal at nine other principal places in the Thames basin is $2 \mathrm{~s}$. $2 \mathrm{~d}$. per head of population, the sum paid to the Company by the Kingston Corporation is only 1s. $6 \frac{3}{4} \mathrm{~d}$.

It would seem, therefore, from every point of view, that before a blind rush is made into bacterial systems, and chemicals are relegated to a back shelf, a careful investigation should be made of what appears to be a happy combination of chemistry and bacteriology, in which each science is male to contribute towards the total result exactly that component in which it is able to work to the greatest advantage. 